\title{
SİGORTA SEKTÖRÜNDE KARA PARA AKLAMA: FATF RAPORLARI VE AKLAMA TIPOLOJILLERI
}

\author{
Nurşen AYDOĞAN* \\ Özgür AKPINAR ${ }^{* *}$
}

\section{Özet}

Finans sektörü içinde önemli bir konumda yer alan sigorta sektörü, kara para aklayıcıları tarafından da suç gelirlerinin aklanması amacıyla kullanılmaktadır. Kara para hacminin tüm dünyada her geçen gün artış eğiliminde olması, bu sektörün de bu tür işlemlerde giderek daha fazla kullanılmasına neden olmaktadır. Kara para ile bağlantılı olmaksızın çok eski tarihlerden beri, söz konusu olan sahte hasarlar, hiç şüphesiz ki, kara para aklayıcıları için de, sigortacılığın en cazip tarafı olmaktadır. Gelişen teknoloji ve piyasa koşulları ile birlikte aklayıcılar farklı yollar ile kara para aklama faaliyetlerini gerçekleştirmektedirler.

Bilindiği üzere, FATF, kara para aklama ve terörün finansmanı ile ilgili güncel trendleri takip etmek ve aklama faaliyetlerinin altında yatan mekanizmaları daha iyi anlayabilmek için dönem dönem tipoloji (aklama vaka örnekleri) çalışmaları yapmaktadır. Böylece hem aklama ve terörün finansmanına yönelik gelişmeleri raporlamak, hem de FATF 40 tavsiye kararlarının güncelliğini ve etkinliğini desteklemek amaçlarına hizmet etmektedir. Bu makalede, 2002-2003, 2003-2004 ve 2004-2005 FATF Kara Para Aklama Tipolojileri raporları ayrı ayrı incelenerek, söz konusu raporların sigortacılığa ilişkin bölümleri özetlenmiştir.

Anahtar kelimeler: Kara para, aklama, sigortacilık, ekonomi, FATF, tipolojiler.

JEL Sınıflaması: G22, G28, K42, O17

\section{MONEY LAUNDERING IN INSURANCE SECTOR: FATF REPORTS AND LAUNDERING TYPOLOGIES}

\footnotetext{
Abstract

The insurance sector, having an important role in the finance industry, provides risk transfer, savings

* TC Ziraat Bankası Genel Müdürlüğü, Müdür, naydogan@ziraatbank.com.tr

* Yrd.Doç.Dr., Marmara Üniversitesi, Bankacılık ve Sigortacılık Yüksekokulu, Sigortacilık Bölümü, oakpinar@marmara.edu.tr
} 
and investment products to a variety of consumers, from individuals to multi-national corporations and governments. These products, like any other financial service, are exposed to a threat of money laundering. The experts view the insurance sector as potentially vulnerable to money laundering because of the size of the industry, the easy availability and diversity of its products and the structure of its business. The Financial Action Task Force (FATF) holds an annual exercise to examine the methods and trends - the typologies - of money laundering and terrorist financing. The primary objective of this work is to obtain material that will help the FATF policy makers develop and refine anti-money laundering and counter-terrorist financing (AML/CFT) standards. In addition, the findings obtained from the annual exercise serve as the basis for informing a wider audience - regulatory authorities, law enforcement agencies and financial intelligence units (FIUs), as well as the general public - on the characteristics and trends of money laundering and terrorist financing. In this article, FATF Typologies Reports of 2002-2003, 2003-2004 and 2004-2005 are examined and typologies of laundering in insurance sector is summarized.

Keywords: Money laundering, insurance, economy, FATF, typologies.

JEL Classification: G22, G28, K42, O17

\section{Giriş}

Kara para aklama, genel olarak, suçtan elde edilen malvarlığı değerlerinin yasal olmayan kaynağının gizlenmesi amacıyla, meşru bir kaynaktan elde edilmiş gelir gibi gösterilmesi yönündeki işlem ve eylemler olarak tanımlanmaktadır. Kara para aklama aynı zamanda, kişilerin suçlarını gizleyebilmek veya suç gelirlerine yasal görüntü kazandırmak amacıyla, suçtan elde ettikleri malvarlığı değerlerinin niteliğini, kaynağını, yerini, durumunu, hareketini ve kime ait olduğunu saklama, örtme veya olduğundan farklı göstermelerine yönelik işlem ve faaliyetler şeklinde de ifade edilmektedir.

Finansal piyasaların en temel unsurlarından birini sigorta sektörü oluşturmaktadır. Sigorta şirketlerinin sigortalılara karşı taahhütlerini tam ve zamanında yerine getirerek ülke ekonomisine gereken desteği verebilmesi, sağlıklı işleyen bir piyasanın varlığına bağlıdır. Sigorta şirketleri de dahil olmak üzere mali kurumlar, müşterilerine çok çeşitli yatırım araçlarını kullanabilme ve fonları bir yerden bir yere transfer edebilme imkanları sunuyor olmaları sebebi ile kara para aklayıcılarının önemli bir hedefi olmaktadırlar.

Sigorta sektörü bugüne kadar, kara para aklama işlemlerinde, diğer faaliyet alanları ölçüsünde kullanılmamış olsa da, kara para hacminin tüm dünyada, her geçen gün artmakta olması, bu sektörün de bu tür işlemlerde giderek, daha fazla kullanılmasına neden olmaktadır. Kara para ile bağlantılı olmaksızın çok eski tarihlerden beri, söz konusu olan sahte hasarlar, hiç şüphesiz ki, kara para aklayıcıları için de, sigortacılığın en cazip tarafı olmaktadır.

Çalışmanın birinci bölümünde sigorta sektörü hakkında genel bilgiler, Türkiye’de ve dünyada sigorta sektörü ile ilgili temel göstergeler incelemiştir. Çalışmanın ikinci ve üçüncü bölümünde kara para aklama kavramı, sigorta sektöründe kara para aklama konuları değerlendirilmiştir. 
Çalışmanın dördüncü ve beşinci bölümünde ise kara para aklama tipolojileri, vaka analizleri ve bulgular incelenmiştir.

\section{Sigorta Sektörü Hakkında Genel Bilgiler}

\section{I. Sigorta Sektörünün Genel Yapısı}

Sigorta sektörü ana hatlarıyla sigorta şirketleri, sigorta acenteleri ve brokerleri ile reasürörlerden oluşmaktadır. Genelde sigorta şirketleri, sigorta teminatını sağlayan ve poliçede belirtilen riskleri belirli bir prim karşılı̆̆ında üstlenen büyük şirketlerdir. Sigorta acenteleri ve brokerleri ise sigorta şirketlerinin poliçelerini satan aracılardır. Bu acente ve brokerlerin bazıları sadece bir sigorta şirketi için çalışır ve onun poliçelerini satarken, diğerleri birden çok sigorta şirketinin ürününü satmaktadır. Piyasanın bu iki ana unsuruna ilaveten destekleyici hizmet sunan sigorta eksperleri, asistans şirketleri gibi ilgili kuruluşlar da piyasanın içinde yer almaktadır.

Sigorta şirketleri sigorta poliçelerinde yer alan riskleri üstlenirler ve bunun karşılı̆̆ında kendilerine prim olarak ödenmesi gereken tutarı hesaplarlar. Sigorta şirketleri poliçelerde sözleşmenin koşullarını ve süresini, tam olarak hangi riskleri karşıladığını, prim ve tazminat tutarını açıkça belirtir. Ne kadarlık prim ödeneceği hayat dışı sigortalarda malın ekonomik değeri, hayat sigortalarında ise sigortalının kendi belirteceği değer üzerinden hesaplanır. Sigorta şirketleri sigortalıların hasar ve tazminatlarını zamanında ve eksiksiz ödeyebilmek için sigortalılardan topladıkları primleri yatırıma yönlendirirler. Hayat sigortası şirketleri, çoğu hayat sigortası ürününün süresinin uzun olması sebebiyle uzun vadeli yatırımları tercih eder.

İki tür sigorta şirketi vardır: Direkt prim üretimi yapan şirketler ve reasürans şirketleri. Direkt sigorta şirketleri poliçeleri düzenleyen, sigortalı ile birebir teması olan şirketlerdir. Sigortalıya ilgili teminatı verirler ve karşılığında prim alırlar. Reasürans şirketleri ise sigorta şirketlerinin sigortalılara düzenlemiş oldukları poliçelere ait riskleri paylaşan şirketlerdir. Reasürans bir nevi sigorta şirketinin kendisini, portföyünü sigorta etmesidir. Sigortalı, reasürans şirketi ile hiçbir şekilde muhatap olmaz. Prim sigorta şirketince tahsil edilir. Riskler, primlerin belli bir oranından veya tutarından feragat etmek koşuluyla sigorta şirketi tarafından reasürans şirketine transfer edilir. Reasürans şirketleri de hasar anında üzerlerine düşen sorumluluk oranında sigorta şirketine sigortalıya ödenmek üzerine ödemede bulunur. ${ }^{1}$

Sigorta şirketleri, müşterilerine çok sayıda sigorta ürünü sunar. Hayat sigortası, sigortadan faydalanacak kişilere, çoğunlukla eşler ve çocuklara, sigortalının ölümü halinde finansal koruma sağlar. Maluliyet sigortaları, yaralanma veya hastalık sonucu çalışamayacak duruma düşen sigortalılara hayatları süresince bir gelir temin eder. Sağlık sigortası, kaza veya hastalık sonucu oluşan tedavi giderlerini öder. Annüite (irat sigortası) emeklilik süresinde belirli bir süre

1 Şenol Serkan Şentürk, "Sigortacılıkta Kara Para ile Mücadele”, İstanbul Marmara Üniversitesi Bankacılık ve Sigortacılık Enstitüsü, 2009, s.19, (Yayınlanmamış Yüksek Lisans Tezi) 
için kişiye düzenli bir gelir sağlar. Öncesinde kişi irat elde etmek için ya peşin olarak toplu bir ödemede bulunur ya da düzenli aralıklarla kendi hesabına kendisi ve/veya işvereni tarafından katkı payı ödemeleri yapılır. Emekli olunca kişinin hesabındaki para kişiye belli aralıklarla (aylık, 3 aylık) düzenli olarak ödenir. Kaza ya da diğer adıyla mal sigortası, yangın, hırsızlık, doğal felaketler gibi tehlikeler sonucu sigortalının malında meydana gelen hasarlara karşı bir teminat sağlar. Sorumluluk sigortası sigortalıyı başkalarının canına ya da malına verdiği zararlara karşı finansal sorumluluktan kurtarır, sigortalının ödeyeceği tazminatı sigorta şirketi öder. Otomobil ya da konut sigortası poliçeleri gibi çoğu poliçe kaza ve sorumluluk sigortalarını birlikte kapsar. Bireysel sigorta ürünlerinin yanında grup sigortaları da mevcuttur. Grup sigortaları bir kaç kişiyi kapsayabileceği gibi milyonlarca kişiyi de kapsayabilir. Grup poliçeleri genellikle çalışanları için işverenlere ya da üyeleri için mesleki organizasyonlara satıllı. En yaygın grup sigortası poliçeleri hayat ve sağlık sigortası grup poliçeleridir. ${ }^{2}$

\subsection{Türkiye'de Sigorta Sektörü ile İlgili Temel Göstergeler}

Türk sigorta sektöründe 2014 yllı sonu itibariyle 38 hayat dışı, 19 hayat ve emeklilik, 5 hayat ve 1 adet reasürans olmak üzere toplam 63 sigorta, reasürans ve emeklilik şirketi faaliyet göstermektedir. Faaliyet ruhsatı olan ancak sözleşme akdetmeyen ya da faaliyeti durdurulmuş olan 2 adet hayat dışı ve 1 adet hayat sigorta şirketi ile 1 adet reasürans şirketiyle birlikte sektördeki toplam şirket sayısı 67 'ye ulaşmaktadır. ${ }^{3}$

Sigorta sektöründe 2014 sonu itibariyle mevcut 38 hayat dışı sigorta şirketinden 26 adedi, 24 hayat ve emeklilik şirketinden ise 18 adedi doğrudan veya dolaylı olarak uluslararası sermayelidir. $\mathrm{Bu}$ şirketlerin 39 adedinde uluslararası sermayenin payı $\% 50$ ve üzerindedir. ${ }^{4}$

"Sigorta sektörü 2014 yılında toplam 26 milyar TL prim üretimi gerçekleştirmiştir. Prim üretiminin 22,7 milyar TL'lik kısmı hayat dışı sigortalara, 3,3 milyar TL'lik kısmı ise hayat sigortalarına aittir. Prim üretiminde hayat dışı branşların payı \% 87 iken hayat dalının payı \% 13 düzeyindedir. Ülkemizde hayat dışı sigortaların geleneksel olarak devam eden toplam prim üretimindeki ağırllğı 2014 yılında da değişmemiştir. Toplam prim üretimi yıl içinde cari fiyatlarla \% 6,9 oranında artmasına rağmen, 1998 yılı sabit fiyatlarıyla \% 1,5 oranında azalmıştır. Reel prim üretimi hayat dışı dallarda \% 0,1 oranında artarken, hayat grubunda \% 11,2 oranında gerilemiştir.”’ 2014 yılında kişi başına düşen prim üretimi ülkemizde 145 dolar olarak gerçekleşmiş olup, dünyada kişi başına prim üretimi 662 dolar olarak gerçekleşmiştir. Direkt prim üretimin GSYH'ye oranı ise ülkemizde \% 1,45 iken, dünyada \% 6,17 düzeyindedir. ${ }^{6}$

Sigorta sektörü gelişmekte olan ülke piyasalarında GSYH'deki değişmelere duyarlılık göstermektedir. Ülkede sigortaya ayrılan pay kişi başına gelir yükseldikçe artmakta ve sonuç

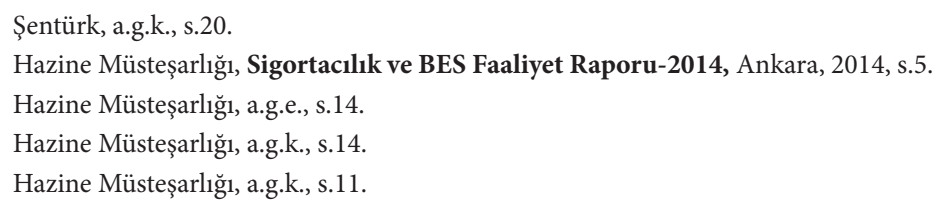


olarak prim üretimi ekonomiden daha hızlı büyümektedir. Bununla birlikte, gelirin azaldığı dönemlerde de sigorta sektörü ekonomiden daha hızlı şekilde küçülmektedir. "Sigorta sektörü ülkemizde de genel anlamda benzer bir durum sergilemekle birlikte, 2014 yllında ters yönde bir gelişme yaşanmış ve GSYH \% 2,87 oranında artarken sigorta sektörü \% 1,5 oranında küçülmüştür. Sonuçta, toplam prim üretiminin GSYH'ye oranı \% 1,51'den \% 1,45’e gerilemiştir."7

Ülkemiz finans sektöründe geleneksel olarak bankacılık sektörü en büyük paya sahiptir. "2014 yılında bankacılık sektörünün aktif toplamı \% 15,11 oranında artarken, emeklilik yatırım fonlarındaki \% 43,75'lik artışın etkisiyle sigorta, reasürans ve emeklilik şirketlerinin aktifleri \% 26,07 oranında yükselmiş ve 81 milyar TL'ye ulaşmıştır. Bu sonuçla sigorta, reasürans ve emeklilik şirketlerinin toplam finansal piyasalar içindeki payı 2013 yılı sonunda \% 3,33 iken 2014 yllı sonunda \% 3,64'e yükselmiştir."

\subsection{Dünyada Sigorta Sektörü ile İlgili Temel Göstergeler}

"Dünya prim üretimi 2014 yllında bir önceki yıla göre \% 3,7 oranında reel olarak artmıştır. Toplam 4,8 trilyon dolar olan prim üretiminin 2,7 trilyon doları hayat, 2,1 trilyon doları ise hayat dışı branşlarda gerçekleştirilmiştir. 2014 yılı prim üretimi hayat branşında $\% 4,3$ ve hayat dışı branşlarda \% 2,9 oranında yükselmiştir.” Dünya toplam prim üretiminde 2014 yılında gelişmiş piyasalar \% 82,4, gelişmekte olan piyasalar ise \% 17,6 oranında bir paya sahiptir.

Dünya nüfusu 2013 yllı itibariyle 7 milyardan fazla bir rakama ulaşmıştır. Ayrıca kişi başı GSMH ise 10.376 dolar olarak gerçekleşmiştir. Bununla birlikte kişi başına düşen sigorta harcaması ise 652 dolar düzeyindedir..$^{10}$ Dünyada sigortanın GSMH'ya oranı \% 6,3 iken, hayat dışı branşlarda toplam prim üretimi 4,5 trilyon dolar civarında gerçekleşmiştir. ${ }^{11}$

Avrupảnın 2013 yllında toplam nüfusu 814 milyona ulaşmıştır. Kişi başına düşen GSMH ise 26.867 dolar olarak gerçekleşmiştir. ${ }^{12}$ Ayrıca Avrupa'da kişi başına düşen sigorta harcaması 1.833 dolar ile dünya ortalamasının oldukça üzerindedir. ${ }^{13}$ Avrupa'da sigortanın GSMH'ya oranı $\%$ 6,8; hayat dışı branşlarda toplam prim üretimi ise 1,5 milyar dolar düzeyinde gerçekleşmiştir. ${ }^{14}$

7 Hazine Müsteşarlı̆̆ı, a.g.k., s.1.

8 Hazine Müsteşarlığı, a.g.k., s. 2-3.

9 Hazine Müsteşarlı̆̆ı, a.g.k., s.10.

10 Swiss Re, World Insurance in 2013: Steering Towards Recovery, 2014, http://media.swissre.com/documents/ sigma3_2014_en.pdf, s.41. Erişim Tarihi (27.01.2016)

11 Swiss Re, a.g.e., s.42. Erişim Tarihi (27.01.2016)

12 Swiss Re, a.g.e., s.42. Erişim Tarihi (27.01.2016)

13 Swiss Re, a.g.e., s.41. Erişim Tarihi (27.01.2016)

14 Swiss Re, a.g.e., s.42. Erişim Tarihi (27.01.2016) 


\section{Kara Para Aklama Hakkında Genel Bilgiler}

Kara para aklama, genel tanımı ile suçtan elde edilen malvarlığı değerlerinin yasal olmayan kaynağının gizlenmesi amacıyla meşru bir kaynaktan elde edilmiş gelir gibi gösterilmesi yönündeki işlem ve eylemlerdir. Kara para aklama aynı zamanda, kişilerin suçlarını gizleyebilmek veya suç gelirlerine yasal görüntü kazandırmak amacıyla, suçtan elde ettikleri malvarlığı değerlerinin niteliğini, kaynağını, yerini, durumunu, hareketini ve kime ait olduğunu saklama, örtme veya olduğundan farklı göstermelerine yönelik işlem ve faaliyetler şeklinde de tanımlanmaktadır.

Suçlular açısından kara para aklamanın iki amacı söz konusudur. Bunlardan ilki, kara paranın elde edilmesi amacıyla işlenen öncül suçtan uzaklaşmaktır. Çünkü büyük miktardaki ve çoğu kez nakit formundaki kara para, bu parayı elinde bulunduran için adeta suçun kanıtı niteliğindedir. Kişinin kanun uygulayıcılar tarafından tespitini kolaylaştırır. Bu nedenle kara paranın bir an önce bu niteliğinden arındırılması, aklanması gerekmektedir. İkincisi ve esas amacı ise, elde edilen kara paranın müsaderesinin önüne geçilmesi ve bu paranın rahat bir şekilde kullanılmasıdır. Çünkü suç örgütleri için suç geliri elde etmek temel amaçtır. Yapılan araştırmalar, suç örgütleri için suç gelirinin ne kadar önemli olduğunu ortaya koymaktadır. Araştırmalar, suç örgütleri için gelirden mahrum kalma riskinin işlenen suç için öngörülen cezadan çok daha önemli ve caydırıcı olduğunu göstermektedir.

Aklama ile mücadele de esas itibarılya bu tespite dayanmaktadır. Suç gelirinden mahrum olmak istemeyen suçlular için ortak nokta, suç gelirini öncül suçtan uzaklaştırmak ve suç geliri için güvenli limanlar bulmak amacıyla her türlü araç ve yöntem kullanarak suç gelirlerini aklamaktır. ${ }^{15}$

Küreselleşme ve finansal piyasaların liberalizasyonu dünya ekonomisi üzerinde birçok olumlu etki yaratmasına rağmen, bu süreç bazı maliyetleri de beraberinde getirmiştir. Sermaye hareketleri üzerindeki sınırlamaların ve kontrollerin kaldırılması ve piyasaların deregülasyonu, uyuşturucu madde kaçakçılığı, silah kaçakçılığı, çocuk ve genç ticareti, beyaz kadın ticareti, organ ticareti, adam kaçırma, şantaj, resmi belgede sahtecilik, ticari hile, sahte damgalı ölçütartı cihazı kullanma, kamu ihalelerine fesat karıştırma, bilimsel ve sınaî casusluk, kasten adam öldürme, hileli iflas, kalpazanlık, vb. gibi suç teşkil eden eylemlerden elde edilen kazançların, bankalar ve diğer mali kurumlar aracıllğıyla ülkeler arasında transfer edilmesini, böylece de suç oluşturan eylemlerde bulunan kişilerin kara paralarını yasal yoldan kazanmış gibi göstermelerini kolaylaştırmaktadır. ${ }^{16}$

\section{Kara Para Aklama ve Sigorta Sektörü}

Finansal piyasaların en temel unsurlarından birini sigorta sektörü oluşturmaktadır. Sigorta şirketlerinin sigortalılara karşı taahhütlerini tam ve zamanında yerine getirerek ülke

15 Hasan Aykın, Aklama ve Terörün Finansmanı ile Mücadelenin Küresel Boyutu, T.C. Maliye Bakanlığı Strateji Geliştirme Başkanlı̆̆ı, Yayın No:2010/406, Ankara, 2010, s.4.

16

Şentürk, a.g.k., s.1. 
ekonomisine gereken desteği verebilmesi, sağlıklı işleyen bir piyasanın varlığına bağlıdır. Sigorta şirketlerinin, gelecekte gerçekleşmesi muhtemel risklerin sebep olacağı kayıp ve hasarların karşılanması taahhüdüyle sigortalılardan topladığı fonların, amacına uygun olarak kullanılması ve bu sürecin sorunsuz şekilde işlemesi ekonomik düzenin ve dolayısıyla genel kamusal düzenin sürdürülebilmesi için bir gerekliliktir. Sigortacılık her şeyden önce güven esasına dayanan bir ticari faaliyettir. Bu bakımdan, sigorta şirketlerinin mali yeterliliğinin sürekli kontrol edilerek sektörün güven içinde faaliyet göstermesi ve geliştirilmesinde kamu yararı bulunduğu düşünülmüş ve sigorta şirketleri devlet denetimine tâbi tutulmuştur. ${ }^{17}$

Sigorta şirketleri de dahil olmak üzere mali kurumlar, müşterilerine çok çeşitli yatırım araçlarını kullanabilme ve fonları bir yerden bir yere transfer edebilme imkanları sunuyor olmaları sebebi ile kara para aklayıcılarının önemli bir hedefi olmaktadırlar. Sigorta şirketlerinin kara paranın aklanmasında araç olarak kullanılmalarının ihtimal dahilinde olması, onları hem ülke içinde hem de uluslararası piyasalarda itibar riski, finansal risk, operasyonel risk ya da cezai yaptırıma uğrama riski gibi risklerle karşı karşıya getirebilmektir. ${ }^{18}$

Sigorta sektörü bugüne kadar, kara para aklama işlemlerinde, diğer faaliyet alanları ölçüsünde kullanılmamış olsa da, kara para hacminin tüm dünyada, her geçen gün artmakta olması, bu sektörün de bu tür işlemlerde giderek, daha fazla kullanılmasına neden olmaktadır. Kara para ile bağlantılı olmaksızın çok eski tarihlerden beri, söz konusu olan sahte hasarlar, hiç şüphesiz ki, kara para aklayıcıları için de, sigortacılığın en cazip tarafı olmaktadır. Sadece İngiltere’de, kasko ve yangın paket poliçelerine ilişkin hasarlarda yapılan sahtekarlı̆̆ın yılda, 1,6 milyar dolar düzeyinde olduğu göz önüne alınırsa, sigorta sektörünün kara para aklamada, ne ölçüde potansiyele sahip olduğu daha net biçimde ortaya çımaktadır.

Örneğin sigorta bedelinin çeşitli sahte işlemlerle gerçek bedelinden yüksek gösterilmesi, sigorta konusunun birden fazla sigorta şirketine sigorta ettirilmesi, kasitlı hasar meydana getirilmesi, sigortasız hasarların sigortalı gibi gösterilmesi vb. hasar meydana geldikten sonra yapılan yolsuzluklar, kara para aklayıcılarının kullanmakta oldukları birkaç yöntemdir. Böylece kara para ile edinilmiş olan her türlü mal ve eşya hasara uğratılarak yasal paraya çevrilmektedir.

Sigorta sektörü sahte hasarların yanı sıra, özellikle hayat sigorta poliçeleri ve emeklilik programları vasıtasıyla da kara para aklama faaliyetlerinde kullanılabilmektedir. Örneğin, yüksek sigorta bedeli olan kısa süreli vefat poliçeleri, sahte ölüm belgeleri düzenlenerek, rahatlıkla yasal paraya çevrilebilmektedir. Bunun yanı sıra, yüksek prim ödemeli ve belli bir süre sonra paraya çevrilebilen hayat poliçeleri, oldukça yüksek miktarda tek prim ödeyerek alınmış emeklilik programları kara para aklanmasında kullanılan diğer ürünler olmaktadır. ${ }^{19}$

17 T. Tiryaki, Türker Gürsoy, "Ekonomik Suç Kavramı ve Sigortacılık Suçlarının Bu Açıdan Değerlendirilmesi”, Sayıştay Dergisi, Sayı 55, Ankara, 2004, s.53.

18 Çağatay Usluoğlu, Dünyada ve Türkiyède Kara Paranın Aklanmasının Önlenmesine İlişkin Düzenlemelerin Türk Sigorta Sektörü Açısından Genel Bir Değerlendirmesi, http://eski.tsrsb.org.tr/private/trk/sayi37/ince37.htm Erişim Tarihi (15.01.2016) 


\section{I. Hayat Sigortaları Yoluyla Aklama}

Hayat sigortaları; müşterinin büyük miktarlı fonları finansal sisteme yerleştirebilmesine ve kaynaklarını gizlemek için iz bırakmadan transferine imkan tanıması, yatırım ve fon biriktirme aracı olması, nakit iştira değeri içermesi, kredi işlemlerinde teminat olarak gösterilebilmesi, sigorta poliçelerinin sigortacının bilgisi dahilinde ya da bilgisi olmadan (hamiline poliçeler) üçüncü bir kişiye devredilebilmesi, erken iptal maliyetine katlanarak sigorta poliçelerinin süresinden önce iptal edilebilmesi, çeşitli yollarla sigorta primlerinin üstündeki tutarlarda ödeme yapılması ve ardından fazla ödenen kısmın iadesinin talep edilmesine olanak tanıması vb. nedenlerle hayat dışı sigortalara göre suç gelirlerinin aklanmasına daha elverişlidir. ${ }^{20}$

\subsection{Hayat Dışı (Elementer) Sigortalar Yoluyla Aklama}

Suçtan elde edilen gelirlerle fonlanan hayat dışı sigorta primleri, sahte hasar talepleri oluşturulması ya da kundaklama gibi hasar talebine yol açacak muvazaalı faaliyetlerle hasar oluşturulması yoluyla sigorta şirketinden hasar ödemesi talebinde bulunulması şeklinde geri istenmekte; böylece yasadışı fonların aklanmış bir şekilde geri alınması mümkün olmaktadır. ${ }^{21}$ Aklayıcı tarafından sigorta şirketine malvarlığının gerçek bedelinden daha düşük bir bedel üzerinden sigortalanan malvarlığı, üçüncü kişilere, kurumlara gerçek bedel üzerinden sigortalanmış gibi gösterilerek, malvarlığı hasara uğradığında/uğratıldığında, hasar, malvarlığının gerçek sigorta bedeli üzerinden karşılanmış gibi gösterilmektir. Gerçekte ise eksik sigorta bedeli ile gerçek sigorta bedeli arasındaki fark aklanan suç gelirlerini oluşturmaktadır.

Hayat/Hayat dışı sigortacılık alanlarında faaliyet gösteren sigorta aracıları da suç gelirlerinin aklanmasında ya da aklanmasının önlenmesinde önemli bir role sahiptirler. Sigorta şirketine bağlı ya da sigorta şirketinden bağımsız çalışan sigorta aracıları poliçe sahibi ile doğrudan ilişki içindedirler. Bu nedenle aklama göstergesi sayılabilecek bir takım faaliyetleri ilk anda gözlemleyebilmektedirler. Hatta çoğu zaman sigorta şirketlerince poliçe sahibi hakkında bilinmeyen hususlar aracılar tarafından bilinebilmektedir.

Sigorta aracılarının (acente, broker) aklamayla mücadele gerekliliği ve yöntemleri, bu amaçla ülkeler tarafından alınan tedbirler (müşterini tanı ilkesi, şüpheli işlem bildirimi vb.) hususlarında bilgi sahibi olmamaları, çok az bilgi sahibi olmaları ya da bu hususlarda ilgisiz ve gayretsiz olmaları nedeniyle, suç gelirlerinin bu kişiler aracılığıyla sigortacı sektörüne yerleştirilmesi kolayca sağlanabilmektedir. Sigorta aracıları, kendileri bizzat suç gelirlerinin sisteme yerleştirilmesi hususunda kanallar oluşturabilmektedirler. Bu nedenle sigorta aracılarının suç gelirleriyle mücadele hususunda bilgilendirmeleri ve bu hususta kendilerine de birtakım önleyici tedbirler uygulanması tüm ülkeler tarafından dikkate alınmaktadır. ${ }^{22}$

20 International Association Of Insurance Supervisors (IAIS), Guidance Paper On Anti-Money Laundering And Combating The Financing Of Terrorism, Guidance Paper No:5, Aralık 2004, s.3.

21 IAIS, a.g.e., s.4.

22 Financial Action Task Force On Money Laundering, Report on Money Laundering Typologies 2003-2004, The Financial Action Task Force (FATF), Paris, 2004, s.15. 


\subsection{Reasürans Yoluyla Aklama}

Aklama sürecini gerçekleştirmek amaciyla sahte reasürans şirketleri kurmak, yasal reasürans şirketleriyle birlikte aklama sürecini tamamlamak amacıyla sahte sigorta şirketleri kurmak, fonların kaynağını saklamak için suç gelirlerinin normal reasürans işlemlerine karışmasını sağlamak reasürans yoluyla aklama yöntemlerindendir.

Reasüransın nakit iştira değeri yoktur ve birikmiş bir değerin üçüncü kişilere transferine imkan vermemektedir. Sigorta poliçesi sahibi ve sigortalı ile reasürör arasında doğrudan bir bağlantı bulunmamaktadır. Dolayısıyla, reasürans şirketlerinin aklama amacıyla kullanılmasına yönelik işlemler, karmaşıklıklarıyla aklamaya karşı doğal bir bariyer oluşturmaktadır. Reasüransın kullanılabilmesi, aklayıcıların kendilerinin sigorta acentesi veya sigorta şirketi kurması ve bundan sonra da reasürans şirketiyle sözleşme imzalamaları yoluyla mümkün olabilecektir. Bu yolun oldukça maliyetli ve zahmetli bir süreç olması nedeniyle, reasürans aklama yöntemi olarak oldukça düşük bir risk taşımaktadır. ${ }^{23}$

\subsection{Bireysel Emeklilik Sistemi Yoluyla Aklama}

Emeklilik sözleşme süresi içinde katılımcı, herhangi bir anda veya sürekli işgöremezlik durumunun ortaya çıkması halinde bireysel emeklilik sisteminden birikimlerini alarak çıkabilmektedir. Katılımcının ayrılma talebinde bulunması halinde bireysel emeklilik hesabındaki birikimler emeklilik sözleşmesi hükümlerine göre ödenmektedir. Katılımcı böyle bir durumda mali bir kayba uğramaktadır. Ancak hayat sigortalarında olduğu gibi, katlanılacak maliyete rağmen, erken iptal yolunun seçilmesiyle aklayıcılar açısından sistemin kullanılması imkan dahilinde gözükmektedir.

Katılımcı emeklilik sözleşmesi yürürlüğe girmeden önce cayma hakkına sahiptir. Bu şekilde şirkete aktarılmış olan olası suç gelirinin, itibarlı bir emeklilik şirketine ait bir çek veya bu şirketten gelen bir banka havalesi olarak aklayıcıya oldukça kısa süre içinde geri dönmesi mümkün görünmektedir. Ancak bu yöntemin kullanılmasıyla niteliği değiştirilebilecek olan paranın "katkı payı veya giriş aidatı” ile sınırlı olması, yöntemi aklama açısından çok da cazip kılmamaktadır.

Emeklilik poliçelerinin aklayıcılar tarafından suiistimal edilmeye çok açık olmadığı yönündeki genel kabul doğrultusunda, konuya ilişkin uluslararası düzenlemelerde kimlik tespitine ilişkin olarak emeklilik poliçelerinde istisnalar getirilmiş ve kolaylaştırılmış CDD (Müşterini Tanı) tedbirleri ile yetinilebileceği ifade edilmiştir. ${ }^{24}$

23 M. Kaya, "Suç Gelirlerinin Aklanmasında Bir Araç Olarak Sigortacılık Sektörünün Kullanılması”, Sosyal Güvenlik Dünyası Dergisi, Sayı 68, Ankara, 2010, s.8. 


\section{FATF Raporları ve Sigorta Sektöründe Aklama Tipolojileri}

Bilindiği üzere, FATF, kara para aklama ve terörün finansmanı ile ilgili güncel trendleri takip etmek ve aklama faaliyetlerinin altında yatan mekanizmaları daha iyi anlayabilmek için dönem dönem tipoloji (aklama vaka örnekleri) çalışmaları yapmaktadır. Böylece hem aklama ve terörün finansmanına yönelik gelişmeleri raporlamak, hem de FATF 40 tavsiye kararlarının güncelliğini ve etkinliğini desteklemek amaçlarına hizmet etmektedir.

Aşağıda 2002-2003, 2003-2004 ve 2004-2005 FATF Kara para Aklama Tipolojileri raporları ayrı ayrı incelenerek, söz konusu raporların sigortacılığa ilişkin bölümleri özetlenmeye çalışılmıştır.

\section{I. FATF 2002-2003 Kara Para Aklama Tipolojileri Raporu}

2002 yılına ilişkin tipoloji çalışmaları, 35 ülkenin katılımıyla, 19-20 Kasım 2002'de Roma’da yapılan uzmanlar toplantısında gerçekleştirilmiştir. Üzerinde çalışılacak konu başlıkları kar amacı gütmeyen organizasyonların terörün finansmanı amaçlı kullanımı, menkul kıymetler ile değerli taşlar ve madenler sektöründe aklama olarak kararlaştırılmış olup, sigorta sektörü ile ilgili vakalar diğer trendler başlı̆̆ı altında yer almıştır. Dolayısıyla ana konular arasında yer alamayan sigortacılıkta aklama örnekleri, FATF XIV. tipoloji çalışmaları çerçevesinde, 2 vaka ile sınırlı kalmıştır. ${ }^{25}$

$\mathrm{Bu}$ örneklerde vurgulanan temel husus hayat sigortası poliçelerinin yatırım özelliği unsurudur. Bunun dışında, sigortacılığın aklama açısından hassas yönlerinin, menkul kıymetler sektörü ile benzerlikler gösterdiği de vurgulanmıştır. Birçok ülkede, hayat sigortası ürünlerine yapılan yatırımların, menkul kıymetlere yapılan yatırımlar gibi görüldüğü dikkat çekmektedir. Ayrıca sigorta sektöründe olduğu gibi, menkul kıymetler sektöründe de aracıların kullanılıyor olması, her iki sektörün aklama açısından zafiyetini oluşturmaktadır.

- Sigorta aracılarının aklama konusunda yeterli eğitime sahip olmadıkları ve temel güdülerinin de, mümkün olduğu kadar çok satış yapmak olduğu göz önüne alındığında, fonların kaynağının tam olarak açıklanmaması, sigorta primlerinin ödenmesinde sıra dışı ödeme yöntemlerinin kullanılması gibi aklamaya yönelik ipuçlarının aracılar tarafından gözden kaçırılması söz konusu olmaktadır.

- $\quad$ Aracıların, poliçelere yönelik operasyonel işlemler üzerinde önemli ölçüde esnekliğe sahip olması da risk unsuru teşkil etmektedir. Müşterilerin daha önceden imzaladıkları talimatlar aracılığıyla poliçelere para yatırma-çekme işlemlerini sadece telefon görüşmesi üzerinden gerçekleştirmeleri, prim ödemelerini aracının kendi hesabından gerçekleştirmesi ve müşteri tarafından nakit olarak/elden kendisine teslim edilmesi gibi uygulamalar yaygın olarak kullanılmaktadır.

25 Financial Action Task Force On Money Laundering, Report on Money Laundering Typologies 2002-2003, The Financial Action Task Force (FATF), Paris, 2004, s. 1-2. 
- $\quad$ Bazı sigorta şirketleri, prim ödemelerinin ilgisiz 3. taraflarca yapılması, çek veya ödeme talimatı gibi yöntemlerle gerçekleştirilmesi halinde aklamaya yönelik ipuçlarını tespit edememektedir.

- Bazı sigorta poliçelerinin, ekstra prim ödeme imkanına sahip olması, müşterilerin ellerindeki fonları, sadece para çekiliş cezası ödemeye katlanmak suretiyle, yatırma-çekme işlemleri yapmalarına olanak tanımaktadır. Böylece fonların sigorta şirketi tarafından müşteriye geri ödenmesi yoluyla, aklayıcı suç ile suç geliri arasındaki bağı karartabilmektedir.

- Sigorta şirketleri acentelerinin çok sayıda alt aracılar kullanması durumunda, oluşan karmaşık ilişkiler piramidini takip edememekte, bu da müşterinin tanınması ve fonlarının kaynağının bilinmesi imkanını da zayıflatmaktadır. ${ }^{26}$

\section{I.I. 2002-2003 Yıllarında Gerçekleşen Vakalar}

\section{- Vaka 1: Suç gelirlerinin sigorta primi ödemesi vasıtasıyla aklanması}

W Şirketi’nin yöneticisi Bay H, her biri farklı ülkelerde kurulmuş iki şirketi kapsayan bir para aklama planı oluşturmuştur. Bu şirketler, Bay H’nin S ülkesindeki hesaplarına, muhtemelen suçtan elde edilmiş ve daha önce bir şekilde finansal sisteme sokulmuş, toplam 1,1 milyon dolardan oluşan fonları transfer etmiştir. Bay H'nin hesabına C ülkesinden de transferler yapılmıştır. Hem vadeli hem de vadesiz pek çok hesap kullanılarak fonlar bir hesaptan diğerine aktarılmıştır. Bu transferlerden biri hayat sigortası poliçeleri satın almak üzere $\mathrm{U}$ ülkesine yapılmıştır. U ülkesinde bu poliçeler için ödenen prim toplamı 1,2 milyon dolardır. $\mathrm{Bu}$ aklama projesinin merkezinde hayat sigortası poliçeleri satın alınması yer almış olup, bu işlem bir aklama operasyonunun son adımını oluşturmuştur. ${ }^{27}$

- Vaka 2: Uyuşturucu parasının hayat sigortası poliçesi ile aklanması

Uyuşturucu ticareti yaptığı iddiası ile tutuklanan bir kişi bir sigorta brokeri vasıtasıyla 250 bin dolar değerinde bir yatırım ürünü satın almıştır. Bu işlemi yaparken izlediği yol ise şöyledir: İlk önce sigorta brokeri ile temas kurmuştur ve ona toplam değeri 250 bin dolar olan 3 taksitte nakit ödemesi yapmıştır. Sigorta brokeri bu tutarda paranın kendisine teslim edildiğini rapor etmemiş ve üç taksidi de bankaya yatırmıştır. Bu durum, brokerin banka ile sürekli bir iş ilişkisi içinde olması sebebiyle bankada broker aleyhinde bir şüphe uyandırmamıştır. Daha sonra sigorta brokeri sigorta şirketine kendisine ait banka hesabından kendi adına yazılı üç çek teslim etmiş olup üç çekin toplamı 250 bin dolar'dır. Ödemeyi üçe bölerek sigorta şirketinin kendisinden şüphelenmesinin önüne geçmeye çalışmıştır. ${ }^{28}$ 


\subsection{FATF 2003-2004 Kara Para Aklama Tipolojileri Raporu}

2003 yılına ilişkin tipoloji çalışmaları, 35 ülkenin katılımıyla, 17-18 Kasım 2003'de Meksika'da yapılan uzmanlar toplantısında gerçekleştirilmiştir. Üzerinde çalışılacak konu başlıkları elektronik fon transferleri ve kar amacı gütmeyen organizasyonların terörün finansmanı amaçlı kullanımı, siyasi nüfuz sahibi kişilerin (PEP) aklama ile olan ilişkileri ve sigorta sektöründe aklama başlıkları altında yer almıştır. Böylece FATF XV. tipoloji çalışmaları tamamlanarak, sonuçlar bir rapor haline getirilmiştir. Bu raporda sigorta sektörü ve kara para aklama ayrı bir ünite olarak ele alınmış ve bir önceki yıla oranla daha kapsamlı biçimde incelenmiştir. ${ }^{29}$

Raporda sigorta sektörü ve kara para ilişkisi hakkında yapılan tespitler aşağıdaki gibi özetlenmiştir:

- Finansal kurumlar, sigorta sektöründen aktarılan fonların, kara para açısından kontrol edilmiş ve temiz olduğunu varsaydığından, aklayıcılar suç gelirlerini sigorta sektörüne sokmayı başardıklarında, yerleştirme ve ayrıştırma aşamalarında önemli bir ilerleme kaydetmiş olmaktadırlar.

- Sektörün büyüklüğü, kolay erişilebilir olması, ürün çeşitliliği ve uzun dağıtım kanallarına sahip olması gibi özellikler, sigorta sektörünü aklama faaliyetlerine karşı hassas hale getirmektedir. Özellikle ana şirketin kontrol ve denetiminden uzak olan dağıtım kanalındaki aracıların varlığı ve poliçe sahibi ile lehdarın farklı kişiler olabilmesi müşterinin tanınması prensibi ilkelerinin layıkıyla yerine getirilememesine sebep olabilmektedir.

- Bu tip risklerin azaltılabilmesi için, pekçok ülke mevzuatında aklama ve terörün finansmanına yönelik yasal tedbirler alınmaktadır. Özellikle "Müşterini Tanı Prensibi” uygulamaları ve şüpheli işlem bildirimi yükümlülüğü mevzuatın önemli hususlarıdır. Sektöre yönelik bu tip ulusal uyum faaliyetlerinin yanı sıra, uluslararası düzeyde IAIS tarafından düzenlenen normlar da temel yaptırımlar arasında yer almaktadır.

- Vaka örneklerinin bir kısmı geçen yıllarda da tespit edilmiş olan yöntemler hakkında önemli ipuçları vermektedir. Özellikle yerleştirme aşamasında, suç gelirleri aklayıcılar tarafından, tercihen bir sigorta aracısından, bir sigorta ürünü satın alınması vasıtasıyla sisteme sokulmaktadır. Bu noktada sigorta aracısının aklama mevzuatına yönelik prosedürleri ne kadar önemsediği, şüpheli işlem bildiriminde bulunulması gereken durumların bildirilip bildirilmediği çok önemlidir. Aklayıcılar bu hususlara gerekli özeni göstermeyen aracıları tercih etmektedir.

- Bu dönemdeki vakalarda dikkat çeken noktalardan biri de, aklama olaylarında şüpheli işlem göstergesi niteliğinde bazı uyarıların varlığıdır. Örneğin müşterinin satın alma aşamasında, poliçenin getirisinden çok iptali ile ilgili işlemlerle ilgilenmesi, nakit ödemeler yapması, tek seferde yüksek meblağlı prim ödemesi gerçekleştirilmesi gibi göstergelerin varlığı, suç gelirlerinin sigorta ürünü aracılığıyla aklanması girişimini akıllara getirmektedir. 
- Offshore merkezleri ile aklama mevzuatı açısından yetersiz ülkelere/ülkelerden yapılan ödemeler ve para transferlerinin söz konusu olması da aklama göstergesi olarak dikkat çekmektedir. Bu tip ülkelerde yetersiz CDD uygulamaları yüzünden, bu bölgelerle iş yapan sigorta şirketlerinin riski iyi yönetebilmek için ekstra dikkatli olmaları gerekmektedir.

- Bir başka aklama yöntemi, özellikle yatırım özelliği taşıyan sigorta poliçeleri için geçerlidir. $\mathrm{Bu}$ yöntemde poliçe sahibinin bir veya birkaç prim üstü ödeme yapması, sonra iade ödemelerinin 3. tarafa yapılmasını talep etmesi, böylece bir yandan poliçenin yatırım özelliğinden faydalanmaya devam ederken, bir yandan da yan ödemeler/iadeler yoluyla suç gelirlerini aklamasıdır.

- Poliçe sahibinin varlığın asıl sahibi olduğu, lehdarın ise sık sık değiştirildiği sigorta ürünlerinde, bir veya birden fazla kompleks aklama vakasının bir arada bulunması da mümkündür.

- İncelenen vakaların bazıları, dikkatli bir sigorta şirketi veya aracı tarafından kolaylıkla fark edilebilecek göstergeler içermektedir. Özellikle tasarruf ve yatırım özelliği içeren sigorta ürünleri aklama yapanlar tarafından daha çok tercih edilmektedir. ${ }^{30}$

\subsection{2003-2004 Yıllarında Gerçekleșen Vakalar}

\section{- Vaka 1: Sigorta poliçesinin aklama için kullanılması}

Kara para aklayıcısı bir kişi transatlantik gemisi için menkul ve kaza sigortaları yaptırmışıtır. Sigortalı yüksek tutarlı primler ödemiş ve sigorta aracılarını da sık sık hasar tazminat talebi yapacak şekilde ikna etmiştir. Ayrıca her zaman için hasar prim oranının şirket lehine olmasına dikkat etmiş, yani aldığı tazminatları ödediği primlerden düşük tutarak, sigorta şirketinin de poliçeden karlı çıkmasını sağlamıştır. Bu yöntemle aklayıcı sigorta şirketinden aldığ 1 çeklerle kara parasını aklamış olmaktaydı. Çekler ünlü bir sigorta şirketine ait olduğundan, üzerinde böyle büyük bir sigorta şirketi adı varken çok az kişi çeklerin veya transferlerin kaynağını sormayı düşünmüştü. ${ }^{31}$

- Vaka 2: Sigorta poliçesinin aklama için kullanılması

$\mathrm{Bu}$ vaka bir çalıntı araba çetesi ve bu arabalara yapılan sigortaların kasıtlı yapılan trafik kazaları sonrası tazmin edilmesiyle kara para aklanması yöntemini içermektedir. A ülkesinde çalınan ve plakaları değiş̧tirilen lüks otomobiller, B ülkesine götürülmekte, burada sahte plakalar ve sahte kimlik belgeleri ile alınmış hurda arabalarla girdikleri düzmece trafik kazaları sonrasında, sigorta tazminatları A ülkesinden talep edilmektedir. Bu sistemde yaklaşık 100 lüks çalıntı araba kullanılmış ve olayın maddi boyutu 2,5 milyon dolara

30 FATF, 2003-2004, a.g.e., s.15.

31 FATF, 2003-2004, a.g.e., s.16. 
ulaşmıştır. Kazaların gerçekleştiği B ülkesinin bu işi için seçilmesinin sebebi, bu ülkenin yasal mevzuatında zarar ödemelerinin çok hızlı gerçekleşmesidir. Bu ödemelerin yapıldığı sahte lehdarlar, elde ettikleri nakidin \% 50'sini, olayları organize eden çete liderine vermekte ve o da bu paraları B ülkesinde otomotiv sektöründe şirketler kurmak ve kamu hizmeti gören araçlar satın almak için kullanmaktadır. Çete liderinin banka hesapları incelendiğinde her ay bu ülkeye yapılan 12.500 dolarlık para transferleri tespit edilmiştir. Yapılan soruşturmalar kapsamında söz konusu çete liderinin çalıntı lüks arabaları sakladığı bir deposu olduğu, ayrıca çetenin suç gelirlerinin bir kısmının yatırımıyla uğraşan emlakçılar ile de bağlantıları bulunduğu ortaya çıkarılmıştır. ${ }^{32}$

\section{- Vaka 3: Aklayıcıların sigorta sektörünü kullanımı}

Sigorta aracılarının devreye girdiği ve müşteri ile ilk teması kurduğu pek çok vakada, müşterilerin kimlik bilgilerinin bu aracılar tarafından tespit edildiği, ancak ana firmanın bu bilgileri teyit etme imkânından yoksun olması veya aracı firmanın bunu nasılsa yapmış olduğu düşüncesiyle ihmal etmesi aklayıcıların işini kolaylaştırmaktadır. Bu şekilde poliçe alan aklayıcı, aradan birkaç ay geçtikten sonra, şartlarının değiştiği gerekçesiyle, poliçeyi sonlandırmak suretiyle, bir miktar zarara katlansa da, parasını aklamış olarak sistemden çıkmaktadır. Bazen de poliçe birkaç yıl bekletilip, sonrasında ödemenin farklı bir 3. tarafa yapılması istemiyle, bir finansal kuruma yatırılmış olmakta, bu kurum da güvenilir bir sigorta şirketinden gelen fonlarda herhangi bir inceleme yapma gereği duymayarak işlemden şüphelenmemektedir. ${ }^{33}$

\section{- Vaka 4: Organize suç gelirlerinin hayat sigortası poliçeleriyle aklanması}

Diğer bir vaka, $X$ ülkesinin gümrük yetkililerinin, sigorta sektörünü kara para aklamada kullanan bir uyuşturucu çetesine ilişkin olarak başlattığı bir soruşturma hakkındadır. Diğer ilgili ülkelerin de katkılarıyla yürütülen ortak çalışmalar sonrasında uyuşturucu çetesinin uyuşturucudan elde ettikleri kara parayı offshore bölgesinde kurulu Z sigorta şirketi vasıtasıyla akladıkları ortaya çıkartılmıştır. Z sigorta şirketi müşterilerine yatırım fonlarına benzer enstrümanlar sunmaktaydı. Bu enstrümanların getiri oranı dünyanın başlıca büyük hisse senedi piyasalarına endeksli olduğundan sigorta poliçeleri yatırım aracı gibi işlem görüyorlardı. Poliçe sahipleri hesaplarını aşırı fonluyor, fonlarını erken nakde çevirmenin cezasını da göze alarak, çeşitli yatırma/çekme işlemleriyle para hareketleri sağlıyorlardı. Sonuçta fonlar ya bir çekle ya da para transferi yoluyla hesaptan çekilerek, sigorta şirketi vasıtasıyla aklanmış oluyordu. Soruşturma kapsamında, bu yöntemle o güne kadar 29 milyon doların aklandığı tespit edilmiş, bunun 9 milyon dolarlık kısmına el konmuştur. Ayrıca, $Y$ ve $Z$ ülkelerinin ortak çabaları sonucunda, $Z$ sigorta şirketi ile bağlantılı pek çok kişi hakkında aklama faaliyetleri sebebiyle tutuklama emri çıkartılmıştır. ${ }^{34}$ 


\subsection{FATF 2004-2005 Kara Para Aklama Tipolojileri Raporu}

Sigorta sektörü, küresel çapta, gerçek kişilerden tüzel kişilere, çokuluslu şirketlerden hükümetlere kadar pek çok gruba risk transferi, tasarruf ve yatırım özelliği taşıyan ürünler sunmaktadır. Bu yüzden, suç gelirlerini bir finansal ürüne yatırarak temizleyebilme arayışı içindeki aklayıcılar için cazip olabilecek sigorta sektörü, diğer finansal sektörlerde olduğu gibi kara para aklama tehdidi altındadır. Bir aklayıcı, suçtan elde ettiği gelirleri, bir sigorta ürününe yönlendirip, sigorta şirketinden bunun karşılı̆̆ında bir geri ödeme elde edebiliyorsa, bu durumda fonlarına yasal bir görünüm kazandırma işlevini yerine getirmiş olacaktır.

FATF tarafından daha önce yapılan tipoloji çalışmaları, sigorta sektörünün yapısal bazı özelliklerinin, sektörü aklamaya karşı hassas hale getirdiğini ve dolayısıyla sektöre özgü bazı riskler doğurduğunu göstermiştir. Özellikle mevzuat ve denetim alanında yeterli standardizasyon sağlanamamış olması, aklayıcıların boşluklardan yararlanmasına olanak sağlamakta, bu yüzden de sektörün büyüklüğüne ve diğer finansal sektörlere nazaran, sigorta sektöründe aklama girişimlerinin tespiti daha düşük düzeylerde kalmaktadır.

FATF tarafından gerçekleştirilen XV. Tipoloji Çalışması, sigorta sektöründeki aklamanın boyutu hakkında yeterli veriye ulaşılamadığı sonucuna varmış olduğundan, bu alanda çalışmak üzere Şubat 2004'de yeni bir tipoloji çalışması (XVI) başlatılmasına karar verilmiştir. Çeşitli ülkelerden finansal istihbarat birimleri, merkez bankaları, sigorta denetçileri gibi uzmanlardan oluşan bir proje ekibi kurularak IAIS gözetmenlerinin de katılımıyla bir araştırma yapılması uygun görülmüştür. Çalışmanın amacı, sigorta sektöründe kara para aklama faaliyetlerine karşı zafiyet oluşturan faktörlerin tespit edilmesidir. ${ }^{35}$

Çalışma kapsamında temel olarak iki kaynaktan veri toplama yoluna gidilmiştir. Bunlardan ilki hazırlanan kapsamlı bir anketin tüm FATF ve IAIS üyelerine gönderilmesidir. İkincisi ise tüm FATF ve MONEYVAL üyelerinden bilgi talep edilmesidir. Böylece birinci yöntemde 46 ülkeden, ikinci yöntemde 25 ülkeden alınan cevaplar derlenerek, toplamda 58 ülkenin katılımıyla dünya toplam sigorta sektörünün önemli bir bölümüne erişim sağlanmıştır. ${ }^{36}$

Çalışma sonucunda 66 tanesi, 14 FATF ülkesi tarafından olmak üzere, toplamda 94 vaka bildirilmiştir. Tüm bu vakaların içerdiği parasal boyut toplam 525 milyon dolar olup, bu hayli dikkat çekici bir miktardır. FATF üyesi ülkelerin bildirdiği 66 vaka toplam 140,6 milyon dolara tekabül etmekte olup, bu rakam vaka başına 2,1 milyon dolara denk gelmektedir. Bu da aklamanın ne kadar ciddi boyutlara ulaşabileceğinin bir göstergesidir.

Vakalar, ortaya çıkarılma kaynakları açısından incelendiğinde, 20 vakanın şüpheli işlem bildirimleri vasıtasıyla, 15 vakanın ise başta yasal incelemeler olmak üzere diğer kaynaklar vasıtasıyla edinildiği bildirilmiştir. Ayrıca 16 vakanın yasal takibe aktarıldığı, 12'sinin ise hala

35 Financial Action Task Force On Money Laundering, Report on Money Laundering Typologies 2004-2005, The Financial Action Task Force (FATF), Paris, 2004, s.41. 
inceleme altında olduğu belirtilmiştir. Vakalar, suç gelirlerinin elde edildiği öncül suç açısından incelendiğinde, uyuşturucu ticaretinin yanı sıra vergi kaçırma, kurumsal dolandırıcılık, muhasebe hesaplarında hilecilik, zimmet gibi finansal sahtecilik suçları başta gelmektedir.

Vakaların sigorta ürünlerine dağılımında ise, \% 65 hayat sigortası ürünleri (520 milyon dolar) \% 30 hayat dışı genel sigortaclık ürünleri (1 milyon dolar) $\% 5$ reasürans ürünleridir. ${ }^{37}$ (4 milyon dolar)

\subsection{2004-2005 Yıllarında Gerçekleşen Vakalar}

- Vaka 1: Tek primli hayat sigortası poliçesi kullanımı

Belçika'da bir hileli iflasta para önce aile üyelerinden birinin hesabına, sonra çek yazılarak bir avukatın hesabına aktarıldı. Avukat paranın bir kısmını hesaba geri iade etti, fakat kalan kısım ile tek ödemeli bir hayat sigortası poliçesi satın aldı. Söz konusu poliçe kısa bir süre sonra iştira edildi ve iştira değeri aile üyesinin hesabına aktarıldı. ${ }^{38}$

- Vaka 2: Erken iştira (zararı bile göze alarak) yönteminin kullanımı

Yine Belçika'da 1 milyon Euro nakit para bir hayat sigortası şirketi hesabına yatırıldı ve iki tek ödemeli hayat sigortası poliçesi satın alındı. Poliçe \% 40 zararla iştira edildi ve söz konusu iştira bedeli ülke dışına çıkartıldı. Burada amaç hileli iflasa giden şirketin içini boşaltmak, şirketin malvarlığını kreditörlerden kaçırmaktı. ${ }^{39}$

- Vaka 3: Yasadışı gelirler ile alınan pahalı mallara ait sigortaların hileli tazminat talebi yöntemi

2004 yılında Norveç’te bir sigortalı evine hırsız girdiği ve 110 bin Norveç Kronu (NOK) değerinde mücevherinin çalındığ 1 ihbarında bulundu. İfadesinde 2,7 milyon NOK değerinde yatını sattığını, alıcının ödemenin 500 bin NOK kısmını mücevherle yaptığını söyledi. 2000 yılında bu kişinin hiçbir geliri yoktu, 2001 yılında 43 bin NOK, 2002 yılında ise 233 bin NOK gelire sahip olduğunu beyan etmişti. Ya bu pahalı teknenin gerçek sahibi değildi ya da tekneyi kara parayla satın almışt1. ${ }^{40}$

- Vaka 4: Nakit ödeme yoluyla sigorta alımı yönteminin kullanılması

Ülke dışında yaşayan 2 yabancı, yüklü miktarda nakit yatırarak 4 hayat poliçesi satın aldılar. Poliçelerin takip eden primleri banka hesapları aracilığıyla yapıldı. Bu banka hesapları araştırıldığında ise, söz konusu hesapların Latin Amerika'dan Batı Avrupa’ya yasadışı narkotik ticareti sebebiyle soruşturma geçirmiş hesaplar olduğu anlaşıld ${ }_{1}{ }^{41}$ 


\section{- Vaka 5: Poliçeye yatırılan paraların aklanması için cayma süresinin kullanılması}

Bay P adına, 25.000 paundluk yatırım tipi sigorta poliçesi satın alındı. Emlak satışından kaynaklanan bu para, Bay P hapiste olduğundan, adına işlem yapma yetkisi olan kızkardeşi tarafından poliçe yatırımına dönüştürülmüştü. Daha sonra kızkardeş, Bay P’nin bu yatırımdan memnun kalmadığını söyleyerek, cayma süresi içinde poliçeyi iptal etti. Böylece, muhtemelen yasadışı yollarla elde edilmiş fonlar, sigortacılık sektörü vasıtasıyla finansal sisteme sokulmuş ve ana kaynağından uzaklaştırılmış oldu. ${ }^{42}$

- Vaka 6: Müşteri ile sigortacının gizlice aralarında anlaşmaları

Kanada'da, bir uyuşturucu madde kaçakçısı 80 bin dolar değerinde bir hayat sigortası poliçesi satın aldı. Poliçenin satın alımı geniş bir satış ağı bulunan bir sigorta şirketinin acentesinden çek kullanılarak yapıldı. Yapılan soruşturma gösterdi ki poliçe uyuşturucu madde kaçakçılığından elde edilen para ile satın alınmıştı. Acente bu kişiye çok yüksek komisyon uygulamıştı. Soruşturmada, poliçenin satın alındıktan 3 ay sonra nakde çevrildiği tespit edildi. ${ }^{43}$

\section{- Vaka 7: Primlerin 3. tarafça ödenmesi}

Bir kar1-koca, birinin ölümü halinde diğerinin lehdar olduğu, yıllık prim ödemeli bir hayat sigortası yaptırdılar. Prim ödemeleri ise, bu çiftin adından değil, yöneticisi oldukları bir şirket tarafından yapılıyordu. Bu durumdan şüphelenilip araştırılması üzerine, söz konusu karı-kocanın büyük çapta ve organize vergi kaçakçılığı yaptıkları ve sigorta işlemlerini bu durumu gizlemek amaçlı gerçekleştirdikleri ortaya çıktı. ${ }^{44}$

\section{- Vaka 8: Uluslararası işlemlere ilişkin riskler}

Bir sigorta şirketine, 4 hayat sigortası poliçesini tek bir poliçeye konsolide etme şeklinde bir teklif gelmişti. Plan şöyleydi: Poliçe sahibi ve 3 ortağı büyük bir bankadan 340 milyon Euro kredi çekip, her biri payına düşen 75 milyon Euro’yu sigorta şirketine yatıracak, kalan 40 milyon Euro ise bankada kalacaktı. Banka kredi vadesi boyunca yıllık \% 6 faiz işletecek, vade sonunda, kredi sigorta şirketi tarafından kapatılacaktı. Böylece poliçeler de bankaya devredilmiş olacaktı.

Uyuşturucu madde kaçakçılığına yönelik olarak yürütülen bir soruşturma kapsamında, sigorta sektörünün aklamada kullanılmasına yönelik örnekler tespit edilmiştir. Uyuşturucu kartelleri uyuşturucudan elde ettikleri paralarla Isle of Man ve Guernsey gibi ülkelerdeki bazı sigorta şirketlerinden pek çok poliçe satın almışlardır. Uzun zamandır süregeldiği anlaşılan bu olayda, kara paranın hayat sigortası poliçelerine yatırıldığı, işlemlerin Kolombiya ve diğer

42 FATF, 2004-2005, a.g.e., s.47.

43 FATF, 2004-2005, a.g.e., s.47.

44 FATF, 2004-2005, a.g.e., s.47. 
Güney Amerika ülkelerinde faaliyet gösteren bir “ana aracı şirket" vasıtasıyla gerçekleştirildiği görülmüştür. Kara paranın poliçelere yatırılış yöntemleri çeşitli olup, bunlar arasında en sık kullanılan 3. taraflarca yapılan elektronik transferlerdir. Söz konusu transferler çoğunlukla döviz büroları tarafından, tek kalemde yüklü bir miktarın sigorta şirketine gönderilmesi şeklinde gerçekleştirilmiştir. İkinci yöntemde ise yine 3. taraflara ait çekler ve bildirim limitlerinin altında kalacak şekilde ayarlanmış transfer talimatları kullanılmıştır. Diğer yöntemde ise aracıların komisyon hesapları kullanılmıştır. Kolombiya'daki müşteriden nakit ödeme alan aracı, bunu hesaplar aracllı̆ııla sigorta şirketlerine aktarmıştır. ${ }^{45}$

\section{- Vaka 9: Hileci müşteriler, sigorta şirketleri ve reasürans şirketleri}

ABD’de faaliyet gösteren A sigorta şirketinin, 1995-2003 yılları arasında sattığı poliçelerde narkotik gelirleri olduğu ve kara para aklama suçu işlediği tespit edilmiştir. Bazı vakalarda kara paralar ölümcül derecede hasta bazı poliçe sahiplerinin sattığı hayat sigortası poliçesinin bir kısmını oluşturmuştur. Diğer bazı vakalarda kara para, sigortalının hastalığının sonuna kadar mevduat gibi şirkette bekletilmiştir. Daha yaygın olarak da bu fonlar, şirketin müşterileri arasında transfer edilerek, şirketin emanet hesapları arasında gelip giden meblağlar için resmi bir dayanak sağlama işlevi görmüştür. Bir aklama olayında ise, A şrketi emanet hesaplarında bir alt hesap açarak, sanki mevduat kabul eden bir bankaymış gibi, müşterinin parasını, herhangi bir sigorta ürünü satmaksızın, sisteme dahil etmiştir.

Bir holding bünyesinde yer alan $\mathrm{Z}$ şirketi, iki sigorta şirketi kurmuştu. Ancak kurucu ortakların gerekli sermayeye sahip olmaması nedeniyle $Z$ şirketi, sigorta şirketlerinden birine 1.000.000 Ruble kredi sağlamıșt. Söz konusu sigorta şirketi diğeriyle günde 40 tane finansal işlem gerçekleştiriyordu. Böylece her iki şirket de lisans almak için gerekli sermayeye sahip oluyordu. Söz konusu sigorta şirketlerinin hem gerçek hem sanal müşterileri vardı. Gerçek ve yasal müşteriler, yasadışı gelirleri gizlemek için paravan olarak kullanıldıklarından, gerekliydi. Şrketlerin elde ettiği sigorta primlerinin \% 90’ bir Rus reasürans şirketler grubuna aktarıliyor, buradan da Kıbrıs ve Karadağdaki offshore şirketlere gönderiliyordu. Primlerin geri kalanı ise belli bir yatırım şirketinin çıkardığı yatırım fonlarına yatırılıyordu. Aynı şekilde yukarıda bahsedilen reasürans şirketleri de bu şirkete yatırım yapmaktaydı. Yatırım şirketi ise bu kağıtların hiçbir zaman kendisine geri dönmeyeceğini biliyor ve buradan elde ettiği fonları kendi finansal aktivitelerinde kullanıyordu. ${ }^{46}$

\section{Bulgular}

Tüm bu tipoloji çalışmalarının ve raporların sonucunda, sigorta sektörüne yönelik olarak ortaya çıan genel resim, sektörün müşterilerine gün geçtikçe daha kompleks yeni finansal ürünler

FATF, 2004-2005, a.g.e., s.48.

FATF, 2004-2005, a.g.e., s.49. 
sunmakta olduğu, ancak bu durumun suçlulara da cazip gelmeye başladığıdır. Ürünlerdeki bu artışa ve çeşitlenmeye paralel olarak, yasadışı kullanımın da artacağı yolunda genel bir bilinç oluşmaması, sektörde risk yaratmaktadır. Bu genel çerçeve dahilinde, sigorta sektörünün aklayıcılar için cazip olmasının nedenleri temel olarak 2 başılı altında gruplanabilir. Her bir bulgunun altında da alt nedenler aşağıda özetlenmiştir. ${ }^{47}$

\section{$\Rightarrow \quad$ Bulgu 1: Sigorta sektöründeki potansiyel aklamaları tespit etmeye yönelik indikatörler}

$\Downarrow \quad$ Sadece sigorta sektörüne özel olmayan genel indikatörler

- Yüksek miktarlı nakit işlemler

- Yanlış adres veya posta kutusu kullanımı

- $\quad$ Riskli ülkelerle denizaşırı işlemler

$\Downarrow \quad$ Poliçe sahipleri karakteristikleri ve davranışları

- Poliçe sahibi bilinen bir suçlu veya bu suçluyla bağlantılı bir kişiyse

- Poliçe sahibinin anormal davranışları mevcutsa

- Geliri ile orantılı olmayan çok yüksek prim ödemeleri yapıyorsa

- Poliçe sahibi erken ödeme/kapatma maliyetlerini önemsemiyorsa

- $\quad$ Poliçe sahibi erken ödeme/kapatma konusu ile fazlasıyla ilgiliyse

- $\quad$ Lehdar değişikliği yapılmışsa

- Müşterinin ekonomik profiliyle uyumsuz bir varlık, sigorta kapsamı içinde yer alıyorsa

- $\quad$ Sigortanın erken ve şüpheli tazmin durumu varsa

$\Downarrow \quad$ Poliçe karakteristikleri ve sahipliğ

- Poliçe ödemelerinin 3. taraflarca yapılması

- $\quad$ Prim ödemelerinin farklı kaynaklardan yapılması

- $\quad$ Prim üstü ödeme yapılmasını takiben 3. tarafa veya yurtdışına geri ödeme talep edilmesi

47 FATF, 2004-2005, a.g.e., s.50. 
- Fon hareketini sağlamak amaçlı olarak bir sigorta şirketinin banka gibi kullanılması

- $\quad$ Erken tazminat talebi

$\Downarrow \quad$ Diğer indikatörler

- Müşteriye ortalamanın üzerinde komisyon işletilmiş olması

- Yeni kurulmuş sigorta veya reasürans şirketlerinin veya geçmişi şeffaf olmayan şirketlerin söz konusu olmasi ${ }^{48}$

\section{$\Rightarrow \quad$ Bulgu 2: Suçluların sigortacılık sektörüne erişimini sağlayacak hassasiyetler}

$\Downarrow \quad$ Kara para aklama mevzuatının sigorta sektörüne uyarlanma şeklinden kaynaklanan hassasiyetler

- Kara para aklama mevzuatının yetersiz uygulanması

- Müşterinin İncelenmesi konusunda 3. taraflara güvenilmesi

- Şüpheli işlem raporlaması

- Genel olarak sigorta ve reasürans sektöründe aklama mevzuatının yetersiz olması

$\Downarrow \quad$ Özel pazar karakteristiklerinden kaynaklanan hassasiyetler

- Uzun dağıtım kanalları

- Aracı teşvikleri

- Artan hacimler ve rekabet baskısı

$\Downarrow \quad$ Sigorta sektöründe kara para aklamanin tespitinin zorluklarından kaynaklanan hassasiyetler

- Sektörün, kara para aklamanın ilk aşamalarına karşı özellikle kırılgan olması

- Aklama hakkında sektörde yeterli bilgi paylaşımı olmaması 
$\Downarrow \quad$ Denetim yetersizliğinden kaynaklanan hassasiyetler

- Aracıların denetiminin yetersizliği

- Yerel mevzuatın uluslararası mevzuat ile uyumlaştırılması

- Reasürans sektöründeki denetim yetersizliği

- İkincil piyasanın kontrolünün eksikliği ${ }^{49}$

Özetlemek gerekirse, sigorta sektöründe kara para aklayıcıların işlerini kolaylaştıran bazı zafiyetler mevcuttur. Diğer sektörlerde de mevcut olan zafiyetlere ilaveten sigorta sektörünün kendine özel zafiyetlerini aşağıdaki şekilde sınıflandırabiliriz.

* Kara para düzenlemelerinin uygulanmasından kaynaklı yetersizlikler

* Piyasanın kendine özgü özelliklerinden kaynaklı yetersizlikler

* Kara parayı tespit etme konusundaki yetersizlikler

* Sektörün yetersiz denetlenmesinden kaynaklı yetersizlikler

Kara para düzenlemelerinin uygulanmasında yaşanan yetersizliklerin önemli nedenlerinden biri kara paraya ilişkin olarak sigorta şirketleri ile sigorta aracıları arasında sorumluluk paylaşımından doğmaktadır. Sigortacılıkta üretimin büyük bir kısmı sigorta aracıları vasıtasıyla yapılır. Dolayısıyla pek çok durumda kara para düzenlemelerinin uygulamasını sigortacılar adına onların aracılarının yerine getirmesi gerekir. Oysa kara paraya ilişkin ilk düzenlemelerde sorumluluk tamamen sigorta şirketlerine yüklenmiş, aracılara ilişkin olarak bazı belirsizlikler kalmıştır. Söz konusu belirsizlikler de kara para düzenlemesinin uygulanmasında çift başlllığa ve yetersizliğe yol açmaktadır. Aracıların kara para düzenlemelerine uyum sağlamaları şart olsa da, müşterilerle iş ilişkisinin nihayetinde sigorta şirketi ile sigortalı arasında kuruluyor olmasından dolayı yanlış bir şekilde aracıların kara para düzenlemelerine uyum sağlamada sorumluluk taşımadıkları varsayılmaktadır. ${ }^{50}$

Sigortacılıktaki prim üretim ilişkisinin pek çok ara kademeyi içermesi (acente, satış elemanı, bölge müdürlüğü, şirket pazarlama departmanı) bu birimler arasındaki koordinasyonda ve dolayısıyla bilgi akışında yaşanacak bozukluklar müşteri hakkında yeterince bilgi sahibi olunmamasına yol açabilir. Kara para aklayıcılar da koşullara göre en zayıf halkasından sisteme girerek bu durumdan yararlanabilir.

Öte yandan acenteler ile sigorta şirketleri arasındaki ilişki ekonomik çıkar temeli üzerine kuruludur ve acentenin bu çıkarı dı̧ında başka şeyleri göz önünde bulundurmaması sık rastlanılan bir durumdur. Fazladan gelir elde etmek amacıyla bazı acenteler ya da onların çalışanları kara para

49 FATF, 2004-2005, a.g.e., s.54.

50 Şentürk, a.g.k., s.22. 
mevzuatını çok da önemsemeyebilirler ya da kara para aklanmasından bilerek istifade etmeye çalışabilirler.

Sigorta sektörü hızla büyümekte ve bankacılık gibi finansal hizmetlerin diğer sektörleriyle rekabet etmektedir. Sektör gittikçe artan bir şekilde müssterilerin ilgisini çekmektedir. Sektörde hayli farklılaştırılmış ürünler hazırlanmaktadır. Ayrıca sigorta piyasası gittikçe artan bir şekilde uluslararası bir nitelik kazanmakta, büyük sigorta şirketleri yeni ve genelde daha riskli az gelişmiş ve gelişmekte olan ülke piyasalarına girmektedirler. Tüm bu gelişmelere bakarsak belki de kara paraya ilişkin yapılan düzenlemeler bu hıza yetişememektedir. Bundan dolayı da düzenleme ve denetleme mekanizmalarının eskisi gibi etkili olamama ihtimali söz konusudur.

Sigorta sektöründe kara para aklanması ihtimalinin düşük olduğuna inanılmaktadır, oysaki sektördeki mevcut risk hiç de ihmal edilebilir cinsten değildir. Sektörün kara para riskinden uzak olduğuna dair mevcut kanaat kamu otoritelerinin sigorta sektörü özelinde önlem almalarında ağır davranılmasına yol açabilmektedir. Sektörde şirketler arasında kara paraya ilişkin olarak bilgi paylaşımı konusunda bir işbirliğine gidilmemiş olması da kara para aklanması teşebbüslerini tespit etmeyi güçleştiren bir durumdur.

Sigorta sektörü daha önce de belirtilmiş olduğu üzere gelişmekte olan ekonomilerde hızlı bir büyüme performansı göstermektedir. Buna mukabil bu ülkelerde sektör henüz tam anlamıyla uluslararası standartlarda denetlenmektedir. Bu durum kara para aklayıcıların ilgisini gelişmekte olan ekonomilerin sigorta sektörlerine çekmektedir. Kara para aklayıcılar bu ülkelerde özellikle de yetersiz denetimin mevcut olduğu hayat-dışı ve de reasürans piyasalarında paravan şirketler kurmak da dahil olmak üzere pek çok yöntemi kullanarak aklama faaliyetinde bulunmaktadırlar. ${ }^{51}$

\section{Sonuç}

Günümüzde, her geçen gün kapsamı ve türleri gelişen ve çeşitlenen organize suç alanları, bu faaliyetlerden elde edilen suç gelirlerinin aklanması ve meşrulaştırılarak finansal sistemin içine sokulması ihtiyacını da beraberinde getirmektedir. Bu ihtiyaç sonucunda, organize suç örgütleri, teknolojik gelişmelerin sunduğu imkânlardan da yararlanarak, birtakım karmaşık işlemler gerçekleştirmekte ve suçtan elde ettikleri gelirlerini gayri meşru kaynağından uzaklaştırarak aklama yoluna gitmektedirler. Suç gelirlerinin aklanması hususunda öteden beri yaygın olarak kullanılan sektör bankacılık sektörü olmakla beraber, günümüzde giderek artan düzeylerde farklı sektörlerde de aklama faaliyetlerine girişilmektedir. Aklama konusunda yasal düzenleme ve denetimlerin yoğunlaştığı alanlardan kaçınarak, henüz keşfedilmemiş, yöntem ve usullerle, daha önce tecrübe edilmemiş sektör ve alanlarda çeşitli işlemler gerçekleştirilmesi, aklayıcıların işini kolaylaştıracağından, sigortacılık sektörü de organize suç örgütleri ve diğer aklayıcıların, aklama faaliyetleri için her geçen gün daha çok yöneldikleri bir sektör haline gelmektedir. 
Sigorta sektörü ana hatlarıyla sigorta şirketleri, sigorta acenteleri ve brokerleri ile reasürörlerden oluşur. Genelde sigortacılar sigorta teminatını sağlayan ve poliçede belirtilen riskleri üstlenen büyük şirketlerdir. Sigorta acenteleri ve brokerleri ise sigorta şirketlerinin poliçelerini satan aracılardır. Bu acente ve brokerlerin bazıları sadece bir sigorta şirketi için çalışır ve onun poliçelerini satarken, diğerleri birden çok sigorta şirketinin ürününü satmaktadır. Piyasanın bu iki ana unsuruna ilaveten destekleyici hizmet sunan sigorta eksperleri, asistans şirketleri gibi ilgili kuruluşlar da piyasanın içinde yer almaktadır.

Sigorta şirketleri, müşterilerine hayat sigortası, maluliyet sigortası, sağlık sigortası, annüite (irat sigortası), sorumluluk sigortası, otomobil ya da konut sigortası gibi çok sayıda sigorta ürünü sunar. Bireysel sigorta ürünlerinin yanında grup sigortaları da mevcuttur. Grup sigortaları bir kaç kişiyi kapsayabileceği gibi milyonlarca kişiyi de kapsayabilir. Grup poliçeleri genellikle çalışanları için işverenlere ya da üyeleri için mesleki organizasyonlara satılır. En yaygın grup sigortası poliçeleri hayat ve sağlık sigortası grup poliçeleridir.

Sigorta sektörü, küresel çapta, gerçek kişilerden tüzel kişilere, çokuluslu şirketlerden hükümetlere kadar pek çok gruba risk transferi, tasarruf ve yatırım özelliği taşıyan ürünler sunar. Bu yüzden, suç gelirlerini bir finansal ürüne yatırarak temizleyebilme arayışı içindeki aklayıcılar için cazip olabilecek sigorta sektörü, diğer finansal sektörlerde olduğu gibi kara para aklama tehdidi altındadır. Bir aklayıcı, suçtan elde ettiği gelirleri, bir sigorta ürününe yönlendirip, sigorta şirketinden bunun karşılığında bir geri ödeme elde edebiliyorsa, bu durumda fonlarına yasal bir görünüm kazandırma işlevini yerine getirmiş olacaktır.

Bilindiği üzere, FATF, kara para aklama ve terörün finansmanı ile ilgili güncel trendleri takip etmek ve aklama faaliyetlerinin altında yatan mekanizmaları daha iyi anlayabilmek için dönem dönem tipoloji (aklama vaka örnekleri) çalışmaları yapmaktadır. Böylece hem aklama ve terörün finansmanına yönelik gelişmeleri raporlamak, hem de FATF 40 tavsiye kararlarının güncelliğini ve etkinliğini desteklemek amaçlarına hizmet etmektedir.

Çalışmamızda 2002-2003, 2003-2004 ve 2004-2005 FATF Kara para Aklama Tipolojileri raporları ayrı ayrı incelenerek, söz konusu raporların sigortacılığa ilişkin bölümleri özetlenmiştir. Bunların özellikle sonuncusu, (2005-2004 FATF Kara Para Aklama Tipolojileri Raporu) önemli bulgular ortaya çıkarmıştır. Çalışma kapsamında temel olarak iki kaynaktan veri toplama yoluna gidilmiştir. Bunlardan ilki hazırlanan kapsamlı bir anketin tüm FATF ve IAIS üyelerine gönderilmesidir. İkincisi ise tüm FATF ve MONEYVAL üyelerinden bilgi talep edilmesidir. Böylece birinci yöntemde 46 ülkeden, ikinci yöntemde 25 ülkeden alınan cevaplar derlenerek, toplamda 58 ülkenin katılımıyla dünya toplam sigorta sektörünün önemli bir bölümüne erişim sağlanmıştır. ${ }^{52}$

Çalışma sonucunda 66 tanesi, 14 FATF ülkesi tarafından olmak üzere, toplamda 94 vaka bildirilmiştir. Tüm bu vakaların içerdiği parasal boyut toplam 525 milyon dolar olup, bu hayli

52 FATF, 2004-2005, a.g.e., s.42. 
dikkat çekici bir miktardır. FATF üyesi ülkelerin bildirdiği 66 vaka toplam 140,6 milyon dolara tekabül etmekte olup, bu rakam vaka başına 2,1 milyon dolara denk gelmektedir. Bu da aklamanın ne kadar ciddi boyutlara ulaşabileceğinin bir göstergesidir. Vakalar, ortaya çıkarılma kaynakları açısından incelendiğinde, 20 vakanın şüpheli işlem bildirimleri vasıtasıyla, 15 vakanın ise başta yasal incelemeler olmak üzere diğer kaynaklar vasıtasıyla edinildiği bildirilmiştir. Ayrıca 16 vakanın yasal takibe aktarıldığı, 12'sinin ise hala inceleme altında olduğu belirtilmiştir. Vakalar, suç gelirlerinin elde edildiği öncül suç açısından incelendiğinde, uyuşturucu ticaretinin yanı sıra vergi kaçırma, kurumsal dolandırıcılık, muhasebe hesaplarında hilecilik, zimmet gibi finansal sahtecilik suçları başta gelmektedir. Vakaların sigorta ürünlerine dağılımında ise, \% 65 ile hayat sigortası ürünleri (520 milyon dolar) \% 30 hayat dışı genel sigortacılık ürünleri (1 milyon dolar) $\% 5$ reasürans ürünleridir. (4 milyon dolar)

FATF tarafından yapılan tipoloji çalışmaları, sigorta sektörünün yapısal bazı özelliklerinin, sektörü aklamaya karşı hassas hale getirdiğini ve dolayısıyla sektöre özgü bazı riskler doğurduğunu göstermiş̧tir. Özellikle mevzuat ve denetim alanında yeterli standardizasyon sağlanamamış olması, aklayıcıların boşluklardan yararlanmasına olanak sağlamakta, bu yüzden de sektörün büyüklüğüne ve diğer finansal sektörlere nazaran, sigorta sektöründe aklama girişimlerinin tespiti daha düşük düzeylerde kalmaktadır. Sigorta sektörüne yönelik olarak ortaya çıan genel resim, sektörün müşterilerine gün geçtikçe daha kompleks yeni finansal ürünler sunmakta olduğu, ancak bu durumun suçlulara da cazip gelmeye başladığıdır. Ürünlerdeki bu artışa ve çeşitlenmeye paralel olarak, yasadışı kullanımın da artacağı yolunda genel bir bilinç oluşmaması, sektörde risk yaratmaktadır. 


\section{Kaynakça}

AYKIN, H., Aklama ve Terörün Finansmanı ile Mücadelenin Küresel Boyutu, T.C. Maliye Bakanlığı Strateji Geliştirme Başkanlığı, Yayın No:2010/406, Ankara, 2010.

ÇUHACI, K., “Kara Para Aklama ve Sigortacilık Sektörü”, Reasürör Dergisi, 48, 2003, s.15-18.

Financial Action Task Force on Money Laundering, Report on Money Laundering Typologies 2002-2003, The Financial Action Task Force (FATF), Paris, 2003.

Financial Action Task Force on Money Laundering, Report on Money Laundering Typologies 2003-2004, The Financial Action Task Force (FATF), Paris, 2004.

Financial Action Task Force on Money Laundering, Money Laundering \& Terorist Financing Typologies 2004-2005, The Financial Action Task Force (FATF), Paris, 2005.

Hazine Müsteşarlığı, Sigortacılık ve BES Faaliyet Raporu-2014, Ankara, 2014.

Hazine Müsteşarlığı, 2014 Yılı Sigortacılık ve Bireysel Emeklilik Faaliyet Raporu Basın Özeti, Ankara, 2014.

International Association of Insurance Supervisors (IAIS), Guidance Paper On Anti-Money Laundering And Combating The Financing Of Terrorism, Guidance Paper No:5, 2004.

KARACAN, Ali İhsan, Sigortacılık ve Sigorta Şirketleri, 1. b. Bağlam Yayıncılık, İstanbul, 1994.

KAYA, M., "Suç Gelirlerinin Aklanmasında Bir Araç Olarak Sigortacılık Sektörünün Kullanılması”, Sosyal Güvenlik Dünyası Dergisi, 68, 2010, s.1-10.

KENDER, Rayegan. Türkiye'de Hususi Sigorta Hukuku, Beta Kitabevi, İstanbul, 2001.

KOCATAŞKIN, Işın, Dünya'da ve Türkiye'de Sigorta ve Reasürans Tarihçesine Kısa Bir Bakış, Lebib Yalkın Yayınları, İstanbul, 1990.

NOMER, Cahit, Sigortanın Temel Prensipleri ve Reasürans, Milli Reasürans Yayınları, İstanbul, 1997.

USLUOĞLU, Çağatay, "Dünyada ve Türkiye’de Kara Paranın Aklanmasının Önlenmesine İlişkin Düzenlemelerin Türk Sigorta Sektörü Açısından Genel Bir Değerlendirmesi”, http://eski.tsrsb. org.tr/private/trk/sayi37/ince37.htm Erişim Tarihi (15.01.2016)

ŞENTÜRK, Şenol Serkan, "Sigortacılıkta Kara Para ile Mücadele”, Marmara Üniversitesi Bankacılık ve Sigortacılık Enstitüsü, İstanbul, 2009. (Yayınlanmamış Yüksek Lisans Tezi)

Swiss Re, World Insurance in 2013: Steering Towards Recovery, 2014, http://media.swissre.com/ documents/sigma3_2014_en.pdf Erişim Tarihi (27.01.2016)

TİRYAKİ, T. ve Gürsoy, T., "Ekonomik Suç Kavramı ve Sigortacılık Suçlarının Bu Açıdan Değerlendirilmesi”, Sayıştay Dergisi, 55, 2004.

Türkiye Sigorta ve Reasürans Şirketleri Birliği, Sigorta Sektöründe İstatistik Çalıştayı, Yayın No:12. TSRŞB Yayınları, İstanbul, 2005.

YANIK, Serhat, Sigorta İşletmeciliği ve Sigorta Ekonomisi, Yayın No:5. Türk Sigorta Enstitüsü Vakfı Ders Notları, İstanbul, 2009, s.53-69. 
